\title{
Policy and scope for practice of ergonomics in Agro Processing Industries in Kerala
}

\author{
Brighty Paulose \\ Research Scholar, Department of Applied Economics, Cochin University of Science \\ and Technology, Kerala, India
}

\section{INTRODUCTION}

Kerala agriculture, over the last few decades has been facing multifaceted challenges, from the conversion of its green land-both wet and garden for the housing well as commercial purposes. The tillers of the land, to a large extent still remain only a producer of raw material in the sector. While the farm land productivity in rupee terms of Kerala agriculture is highest in the country with Rs.53,000/-per hector, the achievement of bottom level farmers still remain pathetic with all profits of value addition swept away by few agents in the industry. Why there is not much value addition done by the basic producers? The answer is clearly the lack of capital base and poor entrepreneurship in the unorganized sector. There are rays of hope in the activities of our new gen agriculture officers who are widely organizing production and marketing activities in rural areas, which may cater to the self-reliance needs of rural farmers. Above all, the most promising area is the value addition sector in agriculture. This includes sub sectors like dairy products and livestock products also. 


\section{New agricultural policy of the state}

In the midst of alarming trend of about $40 \%$ of the farming population of the country waiting to leave the profession on arrival of other opportunities, it is the interest of the state to develop a friendlier environment for agriculturists here.The key areas of empowerment required for farmers for better production and productivity as envisaged by the Kerala state policy for agriculture (2014)are technological skills for production, soil and water management, skills for managing Farmer Producer Organizations(FPOs),skills for cost benefit analysis, marketing skills, IT skills, and skills for managing credit. The FPOs can strengthen the farming community and uplift them from the mere state of raw material producer to the prosperous owner of trading and value addition firms. The aim of the new agricultural policy of the state is to facilitate farmers to yield higher income through the own, operation and earn process of their own agro business firms. Storing, processing, value addition, domestic marketing and export are to be managed by farmers own firms or through their federations. There are also areas like bee keeping, mushroom farming,floriculture,stall fed goat rearing, cage layer poultry rearing, fish rearing, which can be adopted even by farmers with small holdings in the Kerala's present situation of about $95 \%$ of land holdings comes below one hectare.

\section{Need for agro processing industries}

The main activities in the post-harvest session include the processing and preserving of the agricultural product for immediate, intermediate and future and final consumption. Till last decade the employment opportunities were concentrated mostly in the production process. But, by the advent of agro processing industries, it helped to stabilise the employment distribution among production, processing and marketing activities in a more professional way as in any other high profile industries. The scope of agro processing industries are more procyclical with the trend of overall economic development of a society as we can see from examples of developed nations, and also from what we witness now among the enthusiastic entrepreneurs of the present generation. If we check the selected indicators of India 
and Kerala for the periods 1961-2011,the percentage of cultivators ,agricultural labourers, household industry workers and other workers were 20.9,17.4,8.71nd $53.0 \%$ respectively in Kerala during 1961 .The percentage of workers in these respective sectors in India during the same period were 52.8,16.7,6.4, and 24.1\%.The figures for these indicators for 2011 in Kerala shows a reversal trend with only 5.77\% as cultivators, $11.39 \%$ as agricultural labourers,2.35\%in household industries and $80.50 \%$ in the other sector, while there is no such upheavals in India with $24.64 \%, 29.96 \%, 3.81 \%$ and $41.6 \%$ in the respective categories. When there is a drastic shift towards the tertiary sector in Kerala, it's an indicator that the youth must be encouraged to stay in the basic production sector. This is possible only through such incentives which may motivate the educated youth. Such incentives can include easy availability of new technology and the finance for that, better social status, guaranteed returns for the risk of leaving the white colorsector, and of course an entrepreneur friendly environment which always attracts the result oriented youth.

\section{Food processing sector}

It is a sector which links two vital sectors -agriculture and industry. In the scenario of increasing consumption of value added food materials, both as intermediate and final goods, it is expected to boost the food processing industry and it in turn is expected to bring substantial growth to the catering sector ie,agriculture and the whole economy as well. It is a sector which can enhance rural employment to a great extent and there by their standard of living as well. While $19 \%$ of the industrial labor of the country employed in the food processing industry and it is ranked fifth with a 5.5\% contribution to the GDP of the country. The food processing industries which are present and viable in Kerala are processing industries of

1. cereals like rice, wheat and pulses

\section{Dairy products industry}

\section{Fruits and vegetables}

\section{Meat including poultry and bovine}

5.Spices for domestic and export purposes

The journal is a publisher member of Publishers International Linking Association Inc. (PILA)-Crossref (USA). (C) Institute of Research Advances : http://research-advances.org/index.php/IJEMS 
6.Cashew and

7.Oil -coconut.

\section{Ergonomics in Agro based industries}

Ergonomics or human factors as per the International Ergonomic Association is the scientific discipline concerned with the understanding of interactions among humans and other elements of a system and the profession that applies theory, principles, data and methods to design in order to optimize human well-being and overall system performance. Human factors and ergonomics is concerned with the together going between the man, machinery and the environment in which they interact. It takes account of the users' capabilities and limitations in seeking to ensure that tasks, functions, information and the environment suit each user. Physical ergonomics is the sub discipline dealing with designing of user friendly mechanisms and working environment so as to improve the efficiency and ease of the worker. This is also known by the name comfort design which enhances user efficiency by taking into account the interaction between the environment and the human factor.

In agriculture, Ergonomics is a new practice of improving the efficiency of human capital involved in farm based activities or in any other field .This is of particular importance to agriculture where the productivity of the farmer is enhanced using modern machinery in farming ,harvesting as well as in post-harvest sessions. For building up the human resource capacity and thereby to improve the productivity in agriculture, it depends on agricultural education and competency based training to the participants. This requires the system to get changed and the input dealers have to be at the receiving end of scientific and technological knowledge and also to farmers for better skills imparted for the agricultural operations using modern techniques. This will lead to better extension services to farmers-small and marginal, and thereby better production and marketing facilities. The state agricultural policy proposes for state sponsored extension programmes to enhance agripreneurship among small farmers and thereby growing the culture of self-reliant agri-prenures. 


\section{Challenges}

Governments both state and local should work together and evolve a conducive environment for the young entrepreneurs to make their success in agro processing sector which is basically an employment provider to the basic production sector and at the same time requires technologies for the industrial sector. This requires supporting their financial needs like rational tax structure to the sector particularly the innovators and provision of financial assistance to the industrial units, and through promoting the self-reliant markets through NGOs, Cooperatives or Government organizations. Also efforts need to be put in to improve the availability of quality raw materials for processing industries, as the quality standards are a ready reckoner for export products of the industry.

\section{Conclusion}

Recent studies show that Kerala has tremendous potential to grow a viable and high yielding agro processing sector as the future employment cradle of the state. Attracting large scale investments to the sector both in capital and of human resource is the main challenge in the state, which needs committed policy execution and follow up by the state and officials concerned, which is expected and hopefully happening to an extent at present in the state.

\section{References}

(i) Agricultural development policy, (2015), Government of Kerala.

(ii) Alagh, Y.K, (1995), 'Agro-Based Industrialisation in India', in Harish Nayyar and P.RamaSwamy (eds), Globalisation and Agricultural Marketing.

(iii) Alvin R. Tilley \& Henry Dreyfuss Associates (1993, 2002), The Measure of Man \& Woman: Human Factors in Design A human factors design manual. 
(iv) Chadha, G.K and P.P.Sahu (2003), "Small Scale Agro-Industry in India: Low Productivity is Its Achilles Heel", Indian Journal of Agricultural Economics, Vol.58,No.3, pp.518-543.

(v) Human Factors Engineering resources (http://www.humanics-es.com/reccergonomics.htm\#humanfactorsergonomics).

(vi) NABARD (2001), "Food (Mango) Processing in Visakhapatnam and Chittoor Districts", National Bank for Agriculture and rural Development, Evaluation Study Series No.9 Hyderabad Regional Office. 